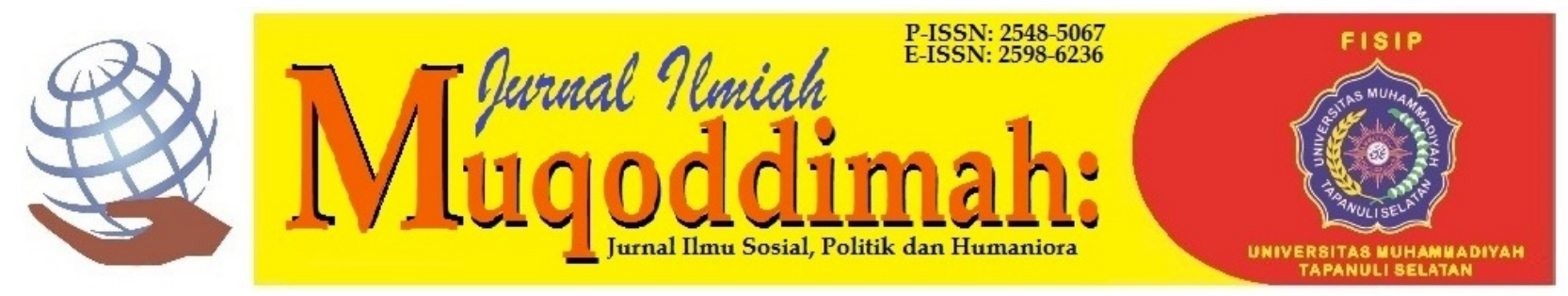

\title{
Kesiapsiagaan Masyarakat Dalam Menghadapi Bencana Alam Kota Padangsidimpuan
}

\author{
Sigit Hardiyanto'), Darmansyah Pulungan²) \\ Universitas Muhammadiyah Tapanuli Selatan \\ JI. St. Mohd. Arief No. 32 Padangsidimpuan, Indonesia \\ sigit12hardiyanto@gmail.com ${ }^{1)}$ \\ darmansyah.pulungan@um-tapsel.ac.id ${ }^{2}$
}

\begin{abstract}
Abstrak
Kota Padangsidimpuan merupakan daerah yang cukup rawan terjadi bencana alam akibat meluapnya sungai Batang Ayumi serta didukung hujan dengan intensitas yang tinggi, bencana alam ini akan berdampak pada kehidupan masyarakat Kota Padangsidimpuan. Tujuan penelitian ini untuk mengetahui bagaimana gambaran kesiapsiagaan masyarakat menghadapi pra bencana alam di Kota Padangsidimpuan, kesiapsiagaan masyarakat menghadapi pascabencana alam di Kota Padangsidimpuan, dan bagaimana upaya Badan Penanggulangan Bencana Daerah Kota Padangsidimpuan dan masyarakat dalam menanggulangi bencana alam di Kota Padangsidimpuan. Metode penelitian yang digunakan dalam penelitian ini adalah metode kualitatif.Hasil penelitian kesiapsiagaan masyarakat menghadapi prabencana dan pasca bencana dengan cara melakukan sosialisasi, simulasi dan membuat KSB (Kampung Siaga Bencana) untuk meminimalisir resiko yang dihadapi masyarakat.
\end{abstract}

Kata Kunci: Kesiapsiagaan, Masyarakat, Mitigasi Bencana Alam

\begin{abstract}
Padangsidimpuan City is an area that is prone to natural disasters due to the overflowing of the Batang Ayumi river and supported by high intensity rain, this natural disaster will have an impact on the lives of the people of Padangsidimpuan City. The purpose of this study was to determine how the description of community preparedness to face pre-natural disasters in Padangsidimpuan City, community preparedness to face post-natural disasters in Padangsidimpuan City, and how the efforts of the Padangsidimpuan City Disaster Management Agency and the community in overcoming natural disasters in Padangsidimpuan City. The research method used in this research is a qualitative method. The results of research on community preparedness to face pre-disaster and post-disaster by conducting socialization, simulation and making KSB (Disaster Alert Village) to minimize the risks faced by the community.
\end{abstract}

Keywords: Preparedness, Community, Natural Disaster Mitigation

\section{PENDAHULUAN}

Bencana alam adalah suatu peristiwa alam yang mengakibatkan dampak besar bagi populasi manusia. Peristiwa alam dapat berupa banjir, letusan gunung berapi, gempa bumi, tsunami, tanah longsor, badai salju, kekeringan, hujan es, gelombang panas, badai tropis, taifun, tornado, kebakaran liar dan wabah penyakit. Seperti Kota Padangsidimpuan sering terjadi bencana alam seperti banjir, tanah longsor dan gempa bumi. Misalnya bencana longsor terjadi di Kelurahan Wek Dua, Lingkungan Lima, Silayang-layang, bencana banjir di dua Kecamatan yaitu Kecamatan Padangsidimpuan 
JURNAL ILMIAH MUQODDIMAH: Jurnal IImu Sosial, Politik Dan Humaniora E-ISSN : 2598-6236

http://jurnal.um-tapsel.ac.id/index.php/muqoddimah
Kesiapsiagaan Masyarakat Dalam Menghadapi Bencana Alam Kota

Padangsidimpuan

(Sigit Hardiyanto, Darmansyah Pulungan)

Utara dan Padangsidimpuan Selatan pada hari Selasa 28 Januari 2020 pukul 15.30 WIB yang lalu yang berakibat 62 unit rumah terendam banjir.

Untuk membantu korban yang terdampak banjir, maka tanggung jawab BPBD Kota Padangsidimpuan adalah pihak yang berwenang dalam mengatasi dan memberikan sosialisasi serta simulasi kepada masyarakat akan pentingnya yang harus dilakukan apabila bencana alam datang di sekitar masyarakat. Kegiatan BPBD Kota Padangsidimpuan dalam hal memberikan sosialisasi dan penyuluhan bencana alam kepada masyarakat di Kota Padangsidimpuan sering dilakukan dikarenakan salah satunya merupakan program kerja yang sangat vital sesuai dengan visinya.

Program sosialisasi yang diberikan bermanfaat untuk mempersiapkan masyarakat dalam menghadapi bencana alam dan kegiatan-kegiatan apa yang dilakukan. Masyarakat dididik untuk menjadi relawan bencana dan diberikan pemaparan dan langkah-langkah menghadapi bencana.Pemberian pemaparan dan langkahlangkah dalam menghadapi bencana tidak hanya satu kali diberikan melainkan bersifat terus menerus.Komunikasi yang diberikan BPBD Kota Padangsidimpuan berupa program kerja yang melibatkan masyarakat. Ini salah satunya bentuk komunikasi efektif yang dilakukan oleh pihak BPBD Kota Padangsidimpuan dalam menjalankan fungsinya sebagai pendamping masyarakat menghadapi bencana.

Hardiyanto (2019:38) menyebutkan bahwa komunikasi yang dilakukan oleh BPBD Kota Padangsidimpuan dalam meminimalisir korban jiwa atas peristiwa bencana alam telah berlangsung secara efektif, sederhana, pendek dan langsung. Informasi yang diberikan kepada masyarakat mengenai bencana meskipun tidak bisa mengelakkan bencana, tidak tahu kapan datangnya bencana setidaknya masyarakat yang harus pertama dilakukan adalah menyelamatkan diri dan mengetahui informasi mengenai tanda-tanda bencana akan datang atau adanya nomor kontak Badan Penanggulangan Bencana Daerah yang dapat di hubungi kapanpun dan dimanapun.

Kesiapsiagaan penanggulangan bencana upaya yang dilaksanakan untuk mengantisipasi kemungkinan terjadinya bencana guna menghindari jatuhnya korban jiwa, kerugian harrta benda dan berubahnya tata kehidupan masyarakat. Sebaliknya suatu kabupaten kota melakukan kesiapsiagaan. Kesiapsiagaan menghadapi bencana adalah suatu kondisi masyarakat yang baik secara individu maupun kelompok yang memiliki kemampuan secara fisik dan psikis dalam menghadapi bencana. Kesiapsiagaan merupakan bagian tak terpisahkan dari manajemen bencana secara terpadu.

Rumusan masalah dari penelitian ini adalah Bagaimana kesiapsiagaan masyarakat menghadapi pra bencana alam di Kota Padangsidimpuan, Bagaimana kesiapsiagaan masyarakat menghadapi pascabencana alam di Kota Padangsidimpuan, dan Bagaimana upaya Badan Penanggulangan Bencana Daerah Kota Padangsidimpuan dan masyarakat dalam menanggulangi bencana alam di Kota Padangsidimpuan.Tujuan penelitian ini adalah untuk mendapatkan gambaran Bagaimana kesiapsiagaan masyarakat menghadapi pra bencana dan pascabencana alam di Kota Padangsidimpuan, dan upaya Badan Penanggulangan Bencana Daerah Kota Padangsidimpuan dan masyarakat dalam menanggulangi bencana alam di Kota Padangsidimpuan. Sedangkan manfaat dari penelitian ini diharapkan dapat memperkaya khasanah penelitian dan pengetahuan sebagai penerapan ilmu sosial dan juga memberikan masukan penelitian lain jika akan mengadakan penelitian yang sama. 


\section{METODE}

Jenis penelitian yang digunakan dalam penelitian ini adalah metode deskriptif dengan analisis kualitatif yaitu suatu metode yang berusaha mencari dan memperoleh informasi mendalam daripada luas atau banyaknya informasi.Penelitian kualitatif menekankan pada analisis induktif, bukan deduktif.

Data yang dikumpulkan bukan dimaksudkan untuk mendukung atau menolak hipotesis yang telah disusun sebelum penelitian dimulai, tetapi abstraksi disusun sebagai kekhususan yang telah terkumpul dan dikelompokkan bersama lewat proses pengumpulan data yang telah dilaksanakan secara teliti (Sutopo, 2006:241). Informan dalam penelitian ini adalah masyarakat Desa Menegen Goti Kota Padangsidimpuan dan personil BPBD Kota Padangsidimpuan

\section{HASIL DAN PEMBAHASAN Kesiapsiagaan}

Kesiapsiagaan menghadapi bencana menurut Fauziah (2006:25) merupakan suatu aktivitas lintas sektor yang berkelanjutan. Kegiatan itu membentuk suatu bagian yang tak terpisahkan dalam sistem nasional yang bertanggungjawab untuk mengembangkan perencanaan dan program pengelolaan bencana seperti pencegahan, mitigasi, kesiapsiagaan, respon, rehabilitasi atau rekonstruksi. Sistem tersebut namanya bervariasi sesuai negaranya bergantung pada koordinasi berbagai sektor yang mengemban tugas-tugas sebagai berikut:

1. Mengevaluasi risiko yang ada pada suatu negara atau daerah tertentu terhadap bencana

2. Menjalankan standar dan peraturan

3. Mengatur sistem komunikasi, informasi dan peringatan

4. Menjamin mekanisme koordinasi dan tanggapan

5. Menjalankan langkah-langkah untuk memastikan bahwa sumberdaya keuangan dan sumber daya lain tersedia untuk meningkatkan kesiapan dan dapat dimobilisasikan saat situasi bencana.

6. Mengembangkan program pendidikan masyarakat

7. Mengoordinasi penyampaian informasi pada media massa

8. Mengorganisasi latihan simulasi bencana yang dapat menguji mekanisme respon atau tanggapan

Tugas sistem kesiapsiagaan adalah:

1. Mengevaluasi risiko yang ada pada suatu negara/ daerah tertentu terhadap bencana

2. Menjalankan standar dan peraturan

3. Mengatur sistem komunikasi, informasi dan peringatan.

4. Menjamin mekanisme koordinasi dan tanggapan

5. Menjalankan langkah-langkah untuk memastikan bahwa sumber daya keuangan dan sumber daya lain yang tersedia untuk meningkatkan kesiapsiagaan dan dapat dimobilsasikan saat situasi bencana.

6. Mengembangkan program pendidikan masyarakat

7. Menggordinasikan penyampaian informasi pada media massa

8. Menggordinasikan latihan simulasi bencana yang dapat menguji mekanisme respon/ tanggapan.

Kesiapsiagaan dalam menghadapi banjir membantu masyarakat dalam membentuk dan merencanakan tindakan apa saja yang perlu dilakukan ketika banjir. Kesuksesan dalam penanganan dan evakuasi/ pengungsian ketika banjir sangat bergantung dari kesiapsiagaan masyarakat dan perseorangan itu sendiri. Ketika banjir terjadi, semua kegiatan akan dlakukan dalam situasi gawat darurat di bawah kondisi yang kacau balau, sehingga perencanaan, koordinasi dan pelatihan dengan baik sangat 
dibutuhkan supaya penanganan dan evakuasi ketika banjir berlangsung dengan baik (Umar, 2013:184).

\section{Masyarakat}

Kata masyarakat berasal dari bahasa Arab, yaitu "syaraka" yang artinya ikut serta, berpartisipasi, atau "musyaraka" yang artinya saling bergaul.Dalam bahasa Inggris dipakai istilah "society".Menurut Koentjaraningrat (dalam Jamaludin, 2015:6) kata tersebut berasal dari bahasa Latin "socius" yang artinya kawan.

Perkembangan masyarakat pada akhirnya menyebabkan terjadinya pengelompokan (penggolongan) atau klasifikasi tipologi masyarakat. Soerjono Soekanto (dalam Jamaludin, 2015: 20) menjelaskan bahwa tahap perkembangan masyarakat Indonesia terdiri atas sebagai berikut:

a. Masyarakat sederhana/ bersahaja adalah masyarakat yang mengalami perkembangan lambat dibandingkan dengan masyarakat lainnya.

b. Masyarakat madya adalah masyarakat yang telah mengalami perkembangan dibandingkan masyarakat sederhana.

c. Masyarakat Pramodern atau Modern adalah masyarakat telah mengalami perkembangan atau mengalami kemajuan karena hubungan dengan masyarakat yang lain telah intensif, banyak menerima informasi dari luar melalui media elektronik, bahkan masyarakat yang bersangkutan sering berusaha diluar wilayahnya sehingga mengalami perkembangan sejalan dengan perubahan yang datang dalam kehidupan mereka.

d. Masyarakat primitif adalah kelompok masyarakat yang masih asli peradaban atau kebudayaannya artinya kebudayaan yang dimiliki tidak bercampur atau pengaruh dari dunia luar.

\section{Mitigasi Bencana Alam}

Secara umum manajemen bencana dan keadaan darurat adalah tahapan prabencana, saat bencana dan pascabencana.Untuk daerah-daerah yang kerap tertimpa bencana, entah itu yang dibuat manusia (banjir, longsor, luapan lumpur, dan lain-lain) dan menerapkan tahapan-tahapan kerja yang lebih mendetail. Setiap tahapan itu sebagai berikut (Khambali, 2017:50):

1. Riset. Pelajari fenomena alam yang akan terjadi secara umum atau khusus disatu daerah. Kontur tanah hingga letak geografis suatu daerah menjadi pengaruh utama penanganan ke depan.

2. Analisis kerawanan dan kajian risiko (vulnerabilities analysis and risk assesment). Ada beberapa variable yang bias menyebabkan bencana ataupun keadaan darurat terjadi di satu daerah. Matrks atas variabel ini patut didaftar untuk kemudian dikaji risiko atau dampaknya jika satu variabel atau panduan beberapa variabel terjadi.

3. Sosialisasi dan kesiapan masyarakat. Pengetahuan atas fenomena alam hingga tindakan antisipasif setiap anggota masyarakat menjadi suatu hal mutlak dilakukan oleh pemerintah ataupun kalangan akademisi yang telah melakukan kajian-kajian dan pemantauan atas fenomena alam didaerahnya.

4. Mitigasi atau persiapan mendekati terjadinya bencana atau keadaan darurat. Persiapan menghadapi banjir di komplek, misalnya dilakukan dengan membersihkan saluran got dan membangun daerah-daerah penyerapan air ke tanah. Setiap minggu ada pemuda karang taruna berkeliling meneriakkan $3 \mathrm{M}$.

5. Warning atau peringatan bencana. Sebagai contoh Gunung Kelud sudah "batuk" cukup parah, sosialisasi bahaya letusan yang lebih besar selayaknya juga dilakukan tak hanya dengan upaya persuasif. 
JURNAL ILMIAH MUQODDIMAH: Jurnal IImu Sosial, Politik Dan Humaniora E-ISSN : 2598-6236

http://jurnal.um-tapsel.ac.id/index.php/muqoddimah
Kesiapsiagaan Masyarakat Dalam Menghadapi Bencana Alam Kota

Padangsidimpuan

(Sigit Hardiyanto, Darmansyah Pulungan)

6. Tindakan penyelamatan. Jika yang terjadi adalah angin putting beliung tentulah tempat yang paling aman berada dibawah tanah dengan kedalaman dan persiapan logistik yang memadai. Jika yang terjadi adalah banjir, penyelamatan barang pribadi ke tempat yang lebih tinggi menjadi kewajiban selain logistic dan perahu karet jika diperlukan.

7. Komunikasi. Faktor komunikasi tetap harus terjaga yang bias dilakukan dengan sistem telepon satelit untuk alat komunikasi langsung agar bala bantuan hingga kepastian keadaan sesaat setelah terjadi bencana bias terdeteksi dari Jakarta ataupun pusar pemerintah provinsi.

8. Penanganan darurat. Jika ada anggota masyarakat yang memerlukan perawatan medis ataupun ada anggota masyarakat yang dinyatakan hilang, kesiapan regu penyelamat harus terkoordinasi dengan baik.

9. Keberlangsung penanganan. Jika banjir tidak surut dalam waktu satu-dua hari ataupun lokasi bencana tak memiliki jalur transportasi yang memadai, upaya yang berkelanjutan adalah kewajiban pemerintah daerah ataupunpusat dengan selalu berkoordinasi di lapangan.

10. Upaya perbaikan. Tahapan pascabencana ataupun pascakeadaan darurat adalah proses pengobatan yang memakan waktu lama

11. Pelatihan dan pendidikan. Untuk mendapatkan hasil terbaik untuk mengantisipasi hingga mengupayakan perbaikan pascabencana, setiap daerah harus memiliki petugas-petugas yang cakap dan berpengetahuan. Untuk itu diperlukan pendidikan dan pelatihan yang selalu sejalan dengan penemuan teknologi penanganan bencana termutakhir.

12. Simulasi. Setelah memiliki petugas yang cakap dan berpengetahuan, setiap daerah harus melaksanakan simulasi penanganan bencana ataupun keadaan darurat agar setiap anggota masyarakat bias mengantisipasi hngga menyelamatkan diri dan anggota keluarganya sehingga beban daerah ataupun kerugian pribadi dapat diminimalisasi.

Peraturan pemerintah No. 21 Tahun 2018 pada Bab 1 Pasal 3 menyatakan bahwa "Penyelenggaraan Penanggulangan Bencana meliputi tahap prabencana, saat tanggap bencana dan pascabencana". Jadi secara umum manajemen bencana dapat dibagi 3 (tiga) kegiatan utama yaitu

1. Kegiatan pra bencana meliputi kegiatan mitigasi dan kesiapsiagaan.

2. Kegiatan pada saat terjadi bencana, berupa kegiatan tanggap darurat

3. Kegiatan pascabencana, berupa kegiatan pemulihan. (Ulum, 2014:13)

\section{Kesiapsiagaan masyarakat menghadapi pra bencana alam di Kota Padangsidimpuan, dan upaya Badan Penanggulangan Bencana Daerah Kota Padangsidimpuan}

Kesiapsiagaan masyarakat merupakan salah satu upaya masyarakat dalam menghadapi pra bencana atau pra bencana.Sebelum menghadapi bencana, masyarakat senantiasa rutin diberikan sosialisasi dan simulasi seperti membuat yel-yel semangat gotong royong saat bencana datang, membuat jalur-jalur evakuasi titik kumpul dan simulasi bencana alam seperti melakukan persiapan ketika bencana datang maka upaya apa saja yang dilakukan untuk meminimalisir resiko yang diakibatkan datangnya bencana alam.Bagi masyarakat, kegiatan ini sangat penting dilakukan sebab kegiatan ini merupakan salah satu bentuk untuk membangun kesadaran masyarakat akan pentingnya kesiapan masyarakat dalam menghadapi bencana serta membangun semangat kegotongroyongan masyarakat Kota Padangsidimpuan yang merupakan daerah yang sangat rawan terjadi bencana alam. Disamping itu sosialisasi juga dapat memberikan manfaat bagi masyarakat agar masyarakat mengetahui apa yang harus dikerjakan dan mengetahui arah yang dituju saat bencana alam datang. Selain itu, Desa 
Menegen Goti merupakan Desa percontohan tanggap bencana sebab selain sering diberikan informasi dan sosialisasi oleh BPBD Kota Padangsidimpuan, Desa ini juga memiliki KSB (Kelompok Siaga Bencana) yang bertujuan untuk membantu masyarakat yang terkena dampak bencana alam.

Penggunaan bahasa juga merupakan hal penting dalam membangun keefektifan dalam pemberian informasi kepada masyarakat. Bahasa yang digunakan pada umumnya adalah bahasa Batak Angkola sebab bahasa itu merupakan bahasa yang digunakan sehari-hari oleh masyarakat Kota Padangsidimpuan misalnya uluni aik manaekyang terjemahannya volume air meningkat, maka masyarakat harus mencari tempat yang lebih tinggi.Kegiatan sosialisasi dan simulasi disambut baik dan antusias oleh masyarakat sebab bagi masyarakat kegiatan ini merupakan kegiatan yang sangat penting dilakukan guna meminimalisirkan bahaya resiko yang diakibatkan oleh bencana alam.

Selain itu kesiapsiagaan masyarakat dalam menghadapi pascabencana, upaya yang dilakukan oleh masyarakat dengan cara membuat tenda darurat, dapur umum, tempat bermain bagi anak anak, dan bersiap-siap menuju jembatan aliran sungai untuk mengambil sampah kayu atau lainnya yang tersangkut di sekitar kolong jembatan guna memuluskan jalannya air agar air tidak meluap dan masuk ke pemukiman masyarakat Kota Padangsidimpuan.

Kesiapsiagaan masyarakat merupakan salah satu upaya masyarakat dalam menghadapi pra bencana atau pra bencana. Salah satu kesiapsiagaan masyarakat dalam menghadapi bencana adalah pentingnya informasi yang diberikanBPBD Kota Padangsidimpuan kepada masyarakat dalam menangani bencana jelas dan ringkas dan punya manfaat selain informasi dalam kesiapsiagaan juga harus dituntut sikap waspada tanggap terhadap bencana seperti pentingnya kebersihan seperti upaya yang dilakukan seperti membersihkan sungai, membuat jalan aliran sungai agar lancar atau mau membersihkan pohon-pohon tumbang pada saat musim-musim hujan tiba. Upaya yang harus dilakukan oleh masyarakat dalam menangani bencana adalah dengan dilakukan tindakan preventif misalnya tidak menebang pohon sembarangan (ilegal loging), memberikan sosialisasi serta simulasi dan bersahabat dengan alam dengan cara menjaga kebersihan dengan tidak membuang sampah ke sungai juga merupakan upaya yang harus dilakukan oleh masyarakat.

\section{SIMPULAN DAN SARAN}

Kesimpulan dari penelitian ini adalah sebagai berikut

1. Kesiapsiagaan masyarakat menghadapi pra bencana alam di Kota Padangsidimpuan dengan cara berbagi informasi terkat kebencanaan baik yang dilakukan BPBD Kota Padangsidimpuan dan masyarakat Desa Managen Goti seperti kegiatan yang harus dilakukan ketika bencana datang, dampak yang ditimbulkan dari bencana alam.

2. Kesiapsiagaan masyarakat menghadapi pascabencana alam di Kota Padangsidimpuan adalah dengan carabersiap-siap menuju aliran air sungai yang ada di jembatan mengambil kayu atau sampah yang tersangkut kolong jembatan, selain itu bantuan dari BPBD juga sigap turun ke masyarakat dalam menanggulangi bencana alam yang datang. Selain itu tindakan yang dilakukan masyarakat antara lain membersihkan pekarangan rumah yang terkena dampak bencana alam seperti banjir.

3. Bagaimana upaya Badan Penanggulangan Bencana Daerah Kota Padangsidimpuan dan masyarakat dalam menanggulangi bencana alam di Kota Padangsidimpuan adalah tindakan preventif misalnya waspada dalam melihat tanda-tanda alam, tidak menebang 
pohon sembarangan (ilegal loging), memberikan sosialisasi serta simulasi dan bersahabat dengan alam dengan cara menjaga kebersihan dengan tidak membuang sampah ke sungai juga merupakan upaya yang harus dilakukan oleh masyarakat.

Saran atau masukan yang diperoleh dari penelitian ini adalah sebagai berikut

1. Diharapkan kerjasama antara BPBD Kota Padangsidimpuan dan masyarakat dalam menanggulangi bencana alam yang terjadi diKota Padangsidimpuan

2. Dalam masyarakat, menanamkan sadar bencana penting dilakukan dengan caramemelihara lingkungan dianggap sebuah tindakan awal seperti tidak membuang sampah ke sungai serta tidak melakukan penebangan pohon secara liar (ilegal loging).

3. Pihak BPBD Kota Padangsidimpuan diharapkan melakukan komunikasi secara intens dengan masyarakat agar masyarakat tahu akan hal-hal berkembang mengenai seputar bencana alam.

\section{UCAPAN TERIMAKASIH}

Peneliti mengucapkan terima kasih sebesar-besarnya kepad Allah SWT yang telah memberikan kesehatan, akal dan ilmu pengetahuan, kepada Direktorat Riset dan Pengabdian Masyarakat DIKTI sebagai pemberi dana penelitian dosen pemula tahun 2020, masyarakat, dan juga kepada BPBD Kota Padangsidimpuan atas kerjasamanya dalam memberikan informasi terkait tema penelitian.

\section{DAFTAR PUSTAKA}

Dewi, Indarti dkk. 2015. Mitigasi Bencana Pada Masyarakat Tradisional Dalam Menghadapi Perubahan Iklim di Kampung Naga Kecamatan Salawu Kabupaten Tasikmalaya. Yogyakarta: Jurnal Manusia dan Lingkungan.

Fauziah, Munaya (Penerjemah). 2006. Bencana Alam Perlindungan Kesehatan Masyarakat. Jakarta: Perpustakaan Nasional.

Haddow, G.D, dan Kims. 2008. Disaster Communications, In A Changing Media World. London. Elsevier.

Hardiyanto, Sigit. 2019. Komunikasi Efektif Sebagai Upaya Penanggulangan Bencana Alam di Kota Padangsidimpuan. Medan: Jurnal Interaksi UMSU

Idrus, Muhammad. 2009. Metode Penelitian IImu Sosial: Pendekatan Kualitatif dan Kuantitatif. Jakarta: Erlangga.

Khambali. 2017. ManajemenPenanggulangan Bencana. Yogyakarta: Andi Yogyakarta. Jamaludin, Adon. 2015. SosiologiPerkotaan. Bandung: Pustaka Setia.

Litlejohn, S.,\& Foss. 2006. Theories of Communication Edisi 7. Belmont, CA: Wadsworth. Moleong, Lexy J, 2002. Metode Penelitian Kualitatif. Bandung: Remaja Rosdakarya. Nawawi. 1998. Metode Penelitian Bidang Sosial. Yogyakarta: Gajah Mada Press. Ruben, Brent. 2013. Komunikasi dan Perilaku Manusia. Jakarta. Raja Grafindo. Sutopo,H.B.2006. Metodologi Penelitian Kualitatif:Dasar Teori dan Terapannya Dalam Penelitian. Edisi-2.Surakarta: Universitas Sebelah Maret.

Ulum, Chazienul. 2014. Manajemen Bencana: Suatu Pengantar Pendekatan Proaktif. Malang: UB Press.

Umar, Nurlailah. 2013. Pengetahuan dan Kesiapsiagaan Masyarakat Menghadapi Bencana Banjir di Bolapapu Kecamatan Kulawi Sigi Sulawesi Tengah. Purwokerto: Jurnal Keperawatan Soedirman.

Undang-Undang Nomor 24 Tahun 2007 Tentang Penanggulangan Bencana

Uripni, Christina. 2003. Komunikasi Kebidanan. Jakarta: Kedokteran EGC.

Watson, J.B. 1934. Psychological Care Of Infant And Child. New York: Norton 